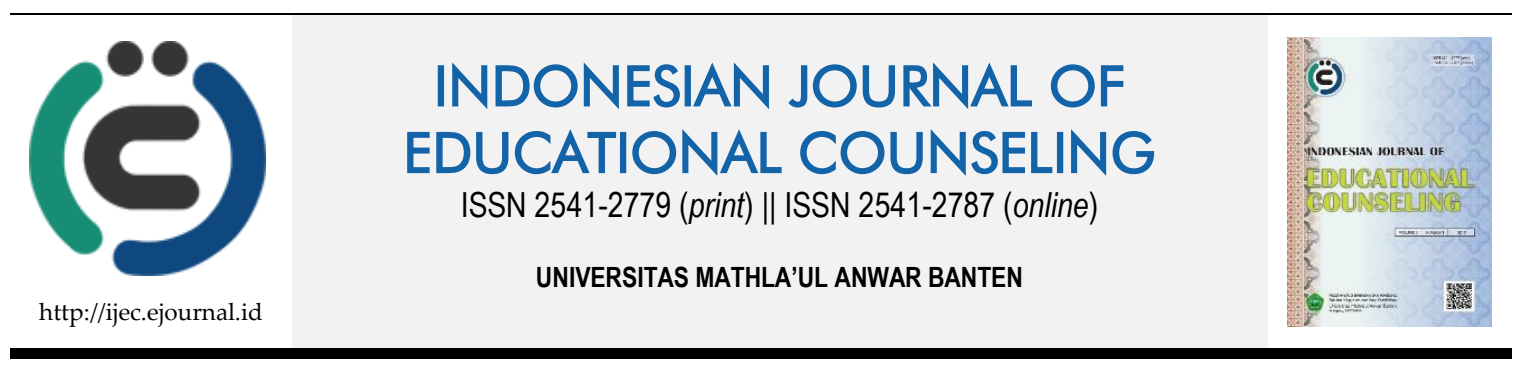

Theoretical/Conceptual Article

\title{
Model Hipotetik: Pendekatan Solution-Focused Brief Counseling (SFBC) dalam Keluarga
}

\author{
Suciani Latif ${ }^{1}$, Musfirah ${ }^{2}$ \\ 1,2 Universitas Negeri Makassar
}

\begin{tabular}{ll}
\hline Article History & ABSTRACT \\
\hline Received: 10.07.2018 & This study is aimed to study hypothetically about Solution-Focused Brief \\
Received in revised form: & Counseling (SFBC) application in family and some example cases of family \\
12.11.2018 & counseling that focused on solution. The SFBC is a post-modern counseling \\
Accepted: 28.01 .2019 & approach that is developed in 1982 by Insoo Kim Berg and De Shazer. SFBC is \\
Available online: 25.01 .2019 & an approach based on counselee strength and potency, and focused to the \\
& solution and future. In solving the problem, SFBC families more focus on \\
nowadays problems and immediately move to build solution to repair family \\
situation. Counselee strength is a primary asset to build solution of the problem. \\
Keywords: Counseling, Dialogue, Family, Solutions.
\end{tabular}

DOI: $10.30653 / 001.201931 .81$

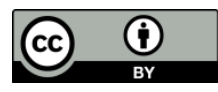

This is an open access article distributed under the terms of the Creative Commons Attribution 4.0 International License, which permits unrestricted use, distribution, and reproduction in any medium, provided the original work is properly cited. (c) 2019 Suciani Latif, Musfirah.

\section{PENDAHULUAN}

Pasangan suami-istri dapat mengalami berbagai masalah sepanjang hubungan mereka. Kesalahpahaman dan masalah dalam komunikasi sehingga terjadi argumen dan perbedaan pendapat. Ketika pasangan mencapai titik kebuntuan beberapa dari mereka memilih mengikuti konseling pasangan untuk membantu mereka memperkuat kemampuan komunikasi mereka dalam upaya menyelamatkan hubungan mereka. Solution-Focused Brief Counseling (SFBC) memberikan pasangan kesempatan untuk fokus isu-isu masalah mereka saat ini dan segera mulai bekerja pada sebuah proses untuk memperbaiki situasi mereka. "Konseling yang berfokus solusi adalah tentang membangun solusi, bukan memecahkan masalah" (Miller \& de Shazer, 2000).

Pasangan suami-istri akan dibantu untuk mengenali kekuatan mereka sendiri, dan merancang intervensi khusus yang dapat membantu situasi mereka yang unik. SFBC memungkinkan konselor dan konseli terlibat dalam pendekatan kolaboratif terhadap penyelesaian masalah mereka. Aspek yang membuat pendekatan ini bermanfaat dalam 
konseling pasangan adalah perspektif terapeutik dan filosofis, peran konselor, teori perubahan dan teknik intervensi menarik yang dapat diterapkan.

Untuk memahami perspektif pendekatan dari SFBC diperlukan pemahaman terhadap asumsi-asumsi filosofisnya. SFBC didasarkan pada asumsi optimis bahwa orang yang sehat dan kompeten, memiliki kemampuan untuk membangun solusi yang dapat meningkatkan kehidupan mereka (Corey, 2009, p. 400). Ketika konseli masuk ke dalam proses konseling, mereka memiliki praduga tentang peran dan alasan mengapa mereka tidak dapat membuat perubahan dalam hidupnya. Jenis prasangka tersebut adalah apa yang menyebabkan konseli menjadi "terjebak" dan merasa tidak berdaya dalam situasi mereka. SFBC adalah model berdasarkan berfokus pada kekuatan konseli sebagai aset yang melekat.

Dalam konsep SFBC, ketika tantangan muncul dalam kehidupan konseli, mereka akan kehilangan kesadaran akan kompetensi pribadi yang mereka miliki. Akibatnya, konseli memiliki perasaan tak berdaya dengan keyakinan bahwa pengalaman negatif masa lalu mereka pasti mempengaruhi masa depan mereka. Konseli seperti ini membutuhkan bantuan dalam menemukan jalan mereka kembali percaya diri akan kompetensi yang mereka miliki dan mempromosikan pandangan positif dan optimis pada kemampuan mereka. SFBC menekankan kekuatan dan resiliensi seseorang dengan berfokus pada eksepsi dari masalah yang mereka hadapi dan mengkonseptualisasikan solusi (Corey, 2009, p. 400).

Setelah konseli mendapatkan kepercayaan diri pada kekuatannya sendiri, konseli dapat mulai membuat perubahan dalam hidup mereka, mengenai apa yang mereka lakukan, bagaimana mereka berinteraksi dengan keluarga atau orang yang mereka cintai, bagaimana berkomunikasi dengan orang lain dan mengekspresikan diri, dan juga mencapai hubungan kuat dengan sistem dukungan dan lingkungan mereka. Fokus pada hal positif memberdayakan konseli untuk berkonsentrasi menyelesaikan masalah saat ini, mereka akan lebih efektif dan akhirnya menjalani hidup mereka dengan cara yang lebih holistik, optimis dan menghargai. Konselor yang kompeten dan kolaboratif akan membimbing menulusuri kekuatan-kekuatan, eksplorasi diri dalam diri konseli.

\section{KAJIAN LITERATUR}

Dalam konsep SFBC, konseli dianggap sebagai 'ahli' pada situasi, tujuan konseling mereka, sehingga dapat membuat solusi untuk masalah mereka sendiri, bukan konselor. SFBC menyebut bukan konselor yang memutuskan apa yang salah (diagnosis) dan treatment apa yang cocok bagi konseli (Walter \& Peller, 1992). Oleh karena itu, posisi konselor adalah 'tidak tahu' (Anderson \& Goolishan, 1992; De Jong \& Berg, 2002) akan kehidupan konseli. Hal ini bukan berarti konselor melepaskan tanggung jawabnya sebagai seorang profesional yang terampil, tetapi hal ini mengisyaratkan bahwa ide konseli akan hargai dan dipandang sebagai sesuatu yang sah (Hoyt \& Berg, 1998).

Selanjutnya, konseli diasumsikan memiliki sumber daya dan kekuatan untuk menyelesaikan masalah mereka (Haley, 2000). Sumber daya tersebut diperkuat, dipuji dan diperluas oleh konselor dalam proses membangun solusi. Konselor akan mengurangi masalah dan patologi, dan lebih mengarahkan wawancara menuju solusi konseli yang menghasilkan kekuatan, kompetensi, dan eksepsi (Walter \& Peller, 1992). Eksepsi adalah saat-saat dimana masalah mestinya hadir namun tidak dalam kehidupan konseli (Walter \& Peller, 1992); mungkin cukup diharapkan terjadi, tetapi tidak (de Shazer, 1985); atau 
terjadi pada tingkat yang lebih rendah (De Jong \& Berg, 2002). Eksepsi untuk setiap masalah ada atau dapat dibuat oleh konseli dan konselor, yang dapat mensugesti munculnya solusi (Bertolino \& O'Hanlon, 2002; De Jong \& Berg, 2002; Walter \& Peller, 1992). Dengan mengidentifikasi eksepsi konselor dapat menantang pandangan yang membatasi dan membantu konseli mengembangkan kontrol atas situasi yang sebelumnya muncul dan dapat diatasi (Walter \& Peller, 1992). Konselor dapat meminta konseli untuk mencari eksepsi-eksepsi di masa lalu, meskipun dalam pendekatan berbasis solusi umumnya berfokus pada saat ini dan masa depan.

SFBC lebih berfokus pada masa sekarang dan akan dating. SFBC menghindari penggalian sejarah individu terlalu dalam, meskipun beberapa pengumpulan informasi merupakan bagian dari kontak klinis (Friedman \& Lipchick, 1999). Konselor perlu menarik perhatian menuju pada apa yang pasangan lakukan atau hal yang berbeda akan mereka lakukan ketika pasangan telah mencapai tujuannya (Hoyt \& Berg, 1998). Dalam prakteknya, konselor lebih menekankan penggunaan bahwa bahasa dalam wawancara.

Bahasa yang digunakan mengasumsikan perubahan ke arah yang diinginkan, serta sebagai kekuatan dan niat positif konseli. Bahasa telah digambarkan sebagai metode tidak langsung yang paling berpengaruh untuk menciptakan konteks di mana perubahan yang dianggap tak terelakkan (O'Hanlon \& Weiner-Davis, 1989: 60). Hasil yang diinginkan dijelaskan dengan pasti, misalnya, "apa yang akan terjadi ketika Anda merasa lebih dekat?". Masalah yang dimaksud dalam bentuk lampau, "Jadi Anda gunakan untuk melawan." Bahasa selanjutnya digunakan dengan lembut untuk menantang pernyataan konseli yang membatasi kemungkinan perubahan (O'Hanlon, \& Beadle, 1997). Misalnya, pernyataan konseli "dia membosankan" maka konselor merefleksikannya sebagai "pada saat Anda inginkan dia lebih menarik".

\section{DISKUSI}

Beberapa poin umum tentang asumsi SFBC dijelaskan dalam persiapan contoh kasus yang akan dibahas di bawah ini. Contoh kasus disajikan untuk menunjukkan pendekatan SFBC, diterapkan untuk pasangan suami-istri. Pak Mars (bukan nama sebenarnya, umur 38 tahun) dan Bu Venus (bukan nama sebenarnya, umur 30 tahun) merupakan pasangan suami istri dan telah menikah selama 14 tahun. Pasangan ini telah pisah rumah dan memutuskan akan bercerai. Pasangan ini memiliki dua anak laki-laki, usia 11 tahun dan 7 tahun.

Contoh kasus ini akan dilengkapi kutipan dialog dari sesi pertama dan kedua. transkrip diselingi dengan komentar untuk menandai gagasan yang disampaikan. Intervensi dan kutipan dapat dikategorikan sebagai berpindah dari menyalahkan dan konflik; menciptakan harapan; dan membangun solusi. Kategori ini dapat secara leluasa digunakan sebagai pedoman untuk proses konseling. Kategori ini secara rinci mendefinisikan tujuan dari setiap intervensi. Misalnya, proses identifikasi eksepsi dapat memiliki efek mengurangi konflik, menciptakan harapan serta menyarankan solusi.

\section{Tidak Saling Menyalahkan dan Menghindari Konflik}

Dalam proses konseling, suami/istri sering menyalahkan yang lain atas kesulitan mereka saat ini. Menyalahkan tidak akan mendorong terjadinya perubahan namun kerjasamalah yang diperlukan dalam konseling pasangan (Hudson \& O'Hanlon, 1991). Mengurangi saling menyalahkan dan konflik merupakan aspek penting dalam intervensi. 
Intervensi SFBC dapat dimanfaatkan dalam pencarian ini. Proses penyelesaian konflik dan mengurangi menyalahkan melalui proses pindah dari keluhan ke tujuan dan kemungkinan pengakuan (O'Hanlon \& Beadle, 1997).

\section{Berpindah dari keluhan ke tujuan}

Deskripsi konseli tentang masalah sering kali memicu konflik dan tanggapan emosional yang kuat pada pasangan mereka. Proses merefleksikan keluhan sebagai tujuan atau hasil yang diinginkan dapat mengurangi efek emosional dan konflik. Konseli sering kurang tajam ketika membahas apa yang mereka inginkan. Misalnya, keluhan konseli "dia tidak pernah mendengarkan" refleksi hasil dari, "Anda ingin merasa didengarkan". Berfokus pada tujuan konseli meningkatkan harapan, terutama tujuan yang bisa dilihat oleh konseli sebagai tujuan yang dapat dicapai (Snyder, Ilardi \& Cheavens, 2000). Mencari tujuan umum adalah sangat penting dalam intervensi pada pasangan, karena cerita-cerita mereka sering terjebak pada gagasan mereka yang tidak memiliki kesamaan (Hudson \& O'Hanlon, 1991). Proses ini dapat difasilitasi dengan pengalaman-pengalaman penting dan nilai-nilai sehari-hari. Berikut kutipan dialog menggambarkan beberapa poin yang dibahas.

Konselor : Apakah ada hal yang penting untuk saya ketahui tentang situasi anda dalam rangka membantu anda saat ini? (Konselor mengambil asusmsi "tidak tahu")

Venus : Saya tidak tahu harus dari mana memulainya...alas an say mengajukan cerai karena iya terus-menurus berbohong, cara dia memperlakukanku dan ia tidak mendengarkan saya.

Konselor : Mmmhhhhhh....

Venus : Mungkin bercerai adalah keputusan terbaik

Konselor : Jadi alasan anda berdua datang ke sini karena anda tidak ingin bercerai? (mengarahkan konseli menuju tujuan bersama)

Mars : Saya sebenarnya tidak menginginkan hal ini. Entah kalau dia?

Konselor : Jadi apa yang harus terjadi dalam sesi ini pada anda berdua sehingga pertemuan ini dapat membantu anda? (mengarahkan konseli pada tujuan)

Venus : Pernyataan. Kami perlu mengungkapkan apa yang mengganggu situasi kami saat ini.

Konselor : Jadi bisa berbagi sesuatu?

Venus : Ya...ada banyak yang belum terselesaikan

Konselor : (Mars) Apa yang dapat menolong atau penting bagi anda agar mendapatkan sesuatu dari konseling ini? (berusaha mendapatkan cara pandang yang seimbang tentang tujuan)

Mars : Mungkin pemahaman yang lebih baik darinya. Dia terlalu cerewet.

Kemungkinan adanya pengakuan

Konseli ingin berbagi pandangan mereka tentang masalahnya dan sering terjadi menyalahkan pasangannya. Meskipun penting untuk mendengarkan dengan hormat cerita konseli, namun konselor perlu mengambil sikap tidak setuju dengan aspek apapun atas sikap menyalahkan atau mematahkan pihak lain. Hal ini penting dalam SFBC 
(Hudson \& O'Hanlon, 1991) untuk merefleksikan cara-cara yang baik yang dapat membuktikan pengalaman dan perlahan-lahan terbukanya kemungkinan. Proses ini telah digambarkan sebagai kemungkinan adanya pengakuan (O'Hanlon \& Beadle, 1997).

Konselor : Jadi dalam pikiran anda istri anda terlalu banyak bicara setiap waktu. Dan hal itu ingin anda lihat sebagai sesuatu yang berbeda dalam hubungan ini? (Memvalidasi pengalaman dan membuka kemungkinan terjadinya perubahan)

Mars : Ya saya pikir begitu. Saya tahu kalau perempuan memang pada dasarnya cerewet, tapi dia sudah keterlaluan

Konselor : Ahh. Dan itu membuat anda kadang-kadang kesulitan? (Mengakui pengalaman dan "kadang-kadang" membuka kemungkinan)

Mars : Ya. Maksudku dia adalah wanita yang ceria tapi dia. . . dia terlalu banyak menuntut, lakukan ini salah...lakukan itu salah, saya tidak pernah benar dimatanya.

Konselor : Ya...begitulah yang anda rasakan (mencatat hal tersebut sebagai pengalaman subjektif, jadi tidak menyalahkan istrinya).

\section{Menciptakan Harapan}

Menciptakan harapan dan ekspektasi merupakan aspek penting dari pencapaian hasil konseling yang positif (Miller, 1999). Banyak teori telah menggarisbawahi pentingnya mengatasi demoralisasi dan membina harapan ketika bekerja dengan pasangan (Young \& Long, 1998). Harapan dan ekspektasi telah diidentifikasi sebagai faktor yang berkontribusi terhadap $15 \%$ dari perubahan dalam konseling (Assay \& Lambert, 1999). Intervensi berorientasi solusi menciptakan harapan melalui bahasa yang mengasumsikan perubahan, dan normalisasi dapat berguna dalam proses ini.

Bahasa yang asumsikan perubahan

Hal ini membantu konseli mengembangkan representasi positif dan menarik dari apa yang mereka ingin lakukan ketika telah mencapai tujuan dan tujuan dan solusi akan dinyatakan dalam bentuk bahasa positif (Walter \& Peller, 1992). Untuk tujuan akhir atau solusi dinyatakan dengan kehadiran sesuatu dan bukan karena tidak adanya sesuatu. Misalnya, ketika konseli memiliki representasi negatif dari tujuan mereka, "dia perlu berhenti mengomel" representasi positif, "dia akan meminta saya dengan suara lembut" adalah lebih baik (Walter \& Peller, 1992).

Penggunaan tense mengasumsikan perubahan akan terjadi atau terjadi tawaran lebih potensial agar pengalaman ini dapat terjadi. Future tense sering digunakan ketika membahas tujuan, hasil yang diinginkan dan solusi. Itu past tense dapat digunakan ketika membahas masalah dan keluhan.

Konselor : (Mars) Apa yang bisa terjadi saat agar anda lebih mudah mendengar ide-ide istri anda? (Memunculkan solusi menggunakan future tense untuk berasumsi bahwa perubahan akan terjadi)

Mars : Dia akan member saran dan bekerja sama dengan saya bukannya mengambil alih. 
Konselor : Ok. Misalkan dia melakukan hal itu, bagaimana hal tersebut akan membuat perbedaan bagi anda? (Future tense mengasumsikan perubahan akan terjadi)

Mars : Pasti semua akan baik-baik saja. Saya akan tahu kalau dia memiliki ide yang baik. ide-idenya bukan ide yang buruk. Tapi selalu mengambil alih dan melakukan segala sesuatunya.

Konselor : Jadi, ide-idenya yang baik, tetapi dia sulit untuk mendengar setiap waktu, dan berbuat berlebihan. (menekankan kompetensi dan kemungkinan pengakuan).

Normalisasi

Konseli saat memasuki sesi konseling melihat masalah mereka sesuatu yang unik. Hal ini berguna untuk membiarkan konseli tahu bahwa respon mereka bisa dipahami dan berbagi satu sama lain (Walter \& Peller, 1992). Proses normalisasi kesulitan konseli dalam konteks kehidupan mereka dapat menggeser sikap menyalahkan satu sama lain dan memungkinkan masalah dilihat sebagai yang bersifat sementara dan bisa dipecahkan. Hal ini dapat meningkatkan harapan dan ekspektasi.

Pada sesi berikutnya, Mars dan Venus akan berbagi pada konselor jadwal padat mereka, termasuk Mars bekerja pada dua pekerjaan dan Venus merawat anak-anak mereka selama 24 jam penuh.

Konselor : Dengan jadwal anda tak heran jika sulit menemukan waktu untuk diri anda sendiri. (Normalisasi)

Venus : Anda tahu apa masalahnya dengan James? dia selalu ingin mengambil anakanak dariku. Kamu mengambil mereka dalam waktu yang lama dan kami tidak mendapatkan waktu bersama-sama.

Mars : Kamu pasti akan melakukan yang sama Saya tidak suka meninggalkan anak-anak di rumah. Saya hanya tidak bisa meninggalkan mereka sendirian di rumah untuk jangka waktu yang lama.

Konselor : Jadi waktu untuk keluarga sangat penting bagi Anda. (dengan asumsi niat positif)

Mars : Ya. Karena saya tidak pernah bisa melihat mereka. Mereka berada di sekolah saat siang dan saya bekerja di malam hari. Saya hanya melihat mereka pada waktu makan malam.

Konselor : Hhhmmmm...masuk akal. Jadi (untuk Venus) Anda bersama anak-anak 24 jam dan anda seperti "Saya ingin istirahat aku harus keluar" dan (Mars) Anda berada di luar rumah sehingga besar keinginan anda melihat mereka ketika anda pulang. (Memvalidasi dan normalisasi)

\section{Membangun Solusi}

Membangun solusi terjadi dalam proses konseling. Hal ini tidak sekadar resiprokal dari mengalami masalah (Hoyt \& Berg, 1998). SFBC dapat dilihat sebagai pendekatan konstruktivis (de Shazer \& Berg, 1992) di mana konselor dan konseli membangun solusi dengan cara yang berbeda dalam melihat pasangan mereka, kesulitan mereka dan interaksi mereka (Hoyt \& Berg, 1998). SFBC menelusuri pengaruh pandangan konseli tentang masalah dengan cara yang mengarah ke solusi (Berg \& Miller, 1992). 
Proses mengeksplorasi dan mengidentifikasi tujuan, hasil yang diinginkan, kompetensi, eksepsi dan kemajuan adalah bagian dari membangun solusi. Sejalan dengan asumsi SFBC yang berfokus pada hal positif atau solusi memfasilitasi adanya perubahan arah (Walter \& Peller, 1992), eksepsi dan solusi yang diperluas dan diperkuat.

Amplifikasi dapat mencakup memuji konseli secara langsung atau tidak langsung. pujian langsung bisa dengan komentar konselor seperti "Wow", "itu luar biasa" atau "Saya terkesan dengan usaha Anda setiap mengambil keputusan". Pujian tidak langsung mencakup mengajukan pertanyaan tentang hal-hal yang positif, eksepsi, solusi dan perubahan. Misalnya "Saya ingin tahu tentang bagaimana Anda berbicara tanpa berdebat", "benarkah?", atau "bagaimana hal itu membuat perbedaan untuk Anda?".

\section{Mengidentifikasi eksepsi}

Dengan bertanya tentang eksepsi konseli diarahkan untuk mencari saat-saat di masa lalu dan masa kini mereka terbebas masalah. Melalui sebuah proses konseli mungkin menemukan solusi yang mereka melupakan, atau yang sebelumnya sudah pernah terjadi tanpa diketahui (O'Hanlon \& Weiner-Davis, 1989). Eksepsi setiap kali perlu diperkuat. Ketika mengidentifikasi dan memperkuat eksepsi dalam treatment pasangan, penting untuk mengeksplorasi kontribusi dan pengalaman mereka, waktu bebas-masalah dari kedua belah pihak.

Konselor : Apakah itu pernah terjadi, kalian mendapatkan waktu bersama? (Memunculkan eksepsi)

Mars : Kami menonton film! Beberapa waktu lalu!

Konselor : Benarkah? Bagaimana kalian melakukannya? (dengan asumsi mereka bekerja bersama-sama)

Venus : Kami terbangun dan langsung pergi! Anak-anak sedang tidur...

Konselor : (Mars) Apakah itu sulit bagi anda mencemaskan anak-anak? Atau apakah hal tersebut baik-baik saja?

James : Saya rasa begitu. Kami pergi ke bioskop dekat rumah kami.

Konselor : Apa yang berbeda tentang saat ini, agar anda membuatnya terjadi? (menguatkan eksepsi)

Venus : Saat itu sangat berbeda. Dia memperlakukan saya dengan baik.

Konselor : Benarkah? (Pujian tidak langsung)

Mars : Saya melihat betapa stresnya dia, dan saya saat itu tidak harus bekerja keesokan harinya.

Konselor : (Yolanda) Apakah yang berbeda dari suami anda yang memperhatikan kalau anda stres dan menyarankan sesuatu seperti ini? (menguatkan pengecualian)

Venus : Ya. Itu adalah kejutan! Hal itu tidak biasanya dia melakukannya, mendadak membawa saya ke suatu tempat.

\section{Memunculkan solusi}

Solusi dapat dimunculkan lebih lanjut melalui eksplorasi kemajuan ke arah yang diinginkan. Hal ini penting untuk memperkuat setiap pola solusi pada pasangan, termasuk penggunaan pujian langsung dan tidak langsung . Berikut kutipan dialog dari 
pasangan pada sesi kedua, dan menandai identifikasi dan amplifikasi dari kemajuan dan solusi yang mereka kembangkan antara sesi.

Konselor : Hal apa yang terjadi sejak sesi terakhir kita? Lebih baik? Sama? Atau lebih buruk?

Mars : Saya pikir terus membaik.

Konselor : Luar biasa. (Venus) Apakah anda juga akan berkata tentang situasi telah lebih baik?

Venus : Ya. Lebih baik. Segala sesuatu semakin baik.

Konselor : Oke. Apa yang telah terjadi secara berbeda yang berfungsi lebih baik untuk anda berdua? (Memunculkan solusi)

Mars : yaa...., saya pikir kami telah menghindari beberapa masalah.

Konselor : Maksudnya argumen-argumen yang dapat menjadi besar?

Mars : Ya. Saya pikir mengenali hal-hal yang dapat memicu pertengkaran. Saat kami mulai mengatakan ini itu, kami langsung berhenti berhenti daripada melanjutkan.

Konselor : dan ini adalah sesuatu yang telah anda lakukan berdua? (Mencatat solusi sebagai sesuatu yang pasangan lakukan bersama)

Mars : Ya. Dia telah menjadi lebih sabar, dan tidak terlalu banyak bicara

Konselor : Wow. Dan itu menjadi hal baik bagi Anda berdua? (memuji dan menguatkan)

Venus : Dia mendengarkan lebih.

Konselor : Benarkah? Anda bercanda?. (Pujian tidak langsung)

Venus : dia sekarang tidak langsung pergi ketika saya sedang mengeluhkan sesuatu.

Terapis : Jadi dia lebih mendengarkan sudut pandang anda. Sebelumnya, anda pernah katakan, betapa pentingnya hal itu untuk anda, untuk didengar seperti itu. Bagaimana perubahan ini terjadi? Kalian pasti telah berpikir tentang banyak hal.

Mars : Saya telah berpikir tentang hal itu dan mencoba untuk menerapkannya, Dan saya telah memutuskan saatnya untuk kami berdua untuk bergerak maju. Saya kira kami telah celah dalah kehidupan kami sehingga kami perlu untuk berusaha lebih dalam, dalam hal memahami satu sama lain dengan lebih baik.

\section{Tindak lanjut}

Pada tindak lanjut ini, konselor perlu melihat kemajuan-kemajuan yang dialami oleh konseli. Kemajuan, solusi dan perubahan terus diperkuat dan dibahas. Pertanyaan berskala (Berg \& de Shazer, 1993) digunakan untuk memantau kemajuan tujuan pasangan tersebut (" 1 " mewakili titik terendah dalam hubungan mereka dan " 10 " mewakili mencapai tujuan mereka dalam hubungan).

\section{SIMPULAN}

Sesi bersama dengan pasangan dalam konseling merupakan tantangan yang unik bagi konselor, termasuk mengakui pandangan yang berbeda sambil mempertahankan 
aliansi kerja dengan dua konseli dan mengelola konflik dan intensitas emosional, selain memfasilitasi percakapan konseling. SFBC menekankan pada memanfaatkan kompetensi, kekuatan dan sumber daya yang unik konseli untuk menyelesaikan masalah yang pasangan hadapi. Pendekatan SFBC dan intervensi terkait dapat diterapkan secara efektif pada populasi pasangan. Intervensi termasuk mengidentifikasi tujuan, eksepsi dan solusi; menggunakan bahasa yang mengasumsikan perubahan dan membuka kemungkinan; dan memperkuat dan memuji pola solusi. Hal ini dapat membantu proses mengurangi sikap menyalahkan dan konflik, menciptakan harapan dan membangun solusi, merupakan aspek penting dari hasil konseling yang positif pada pasangan.

\section{REFERENSI}

Anderson, H., \& Goolishan, H. A. (1992). The client is the expert: A not-knowing approach to therapy. In S. McNamee \& K. J. Gergen (Eds.), Therapy as social construction (pp. 2539). Newbury Park, CA: Sage.

Assay, T. P., \& Lambert, M. J. (1999). The empirical case for the common factors in therapy: Quantitative findings. In M. A. Hubble, B.L. Duncan, \& S. D. Miller (Eds.), The heart and soul of change: What works in therapy (pp.33-56). Washington DC: APA Press.

Berg, I. K., \& de Shazer, S. (1993). Making numbers talk: Language in therapy. In S. Friedman (Ed.), The new language of change: Constructive collaboration in psychotherapy (pp. 5-24). New York: Guildford Press.

Berg, I. K. (1994). Family based services: A solution-focused approach. New York: Norton.

Berg, I. K., \& Miller, S. D. (1992). Working with the problem drinker: A solution-focused approach. New York: Norton.

Bertolino, B., \& O'Hanlon, B. (2002). Collaborative, competency-based counseling and therapy. Needham Heights: Allyn \& Bacon.

Corey, G. 2009. Theory and Practice of Counseling and Psychotherapy. Belmont, CA: Brooks/Cole.

De Jong, P., \& Berg, I. K. (2002). Interviewing for Solutions. Pacific Grove: Brooks/Cole Publishing.

De Shazer, S., \& Berg, I. K. (1992). Doing therapy: A post-structural revision. Journal of Marital and Family Therapy, 18(1), 71-81.

De Shazer, S. (1985). Keys to solution in brief therapy. New York: Norton.

Dzelme, K., \& Jones, R. A. (2001). Male cross dressers in therapy: A solution-focused perspective for marriage and family therapists. The American Journal of Marriage and Family Therapy, 29, 293-305.

Fischer, R. L. (2004). Assessing client change in individual and family counseling. Research on Social Work Practice, 14(2), 102-111. 
Friedman, S., \& Lipchick, E. (1999). A time-effective, solution-focused approach to couple therapy. In J. Donovan (Ed.), Short-term couple therapy (pp. 325-359). New York: The Guilford Press.

Gingerich, W. J., \& Eisengart, S. (2000). Solution-focused brief therapy: A review of outcome research. Family Process, 39(4), 477-498.

Gingerich, W. J., \& Wabeke, T. (2001). A solution-focused approach to mental health intervention in school settings. Children and Schools, 23(1), 33-47.

Haley, T. (2000). Solution-focused counselling with a sexual abuse survivor. Guidance and Counselling, 15(4), 18-22.

Hoyt, M. F., \& Berg, I. K. (1998). Solution-focused couple therapy: Helping clients construct self-fulfilling realities. In M. F. Hoyt (Ed.), The handbook of constructive therapies (pp. 314-340). San Francisco: Jossey-Bass Publishers.

Hubble, M., \& Miller, S. (1999). The heart and soul of change: What works in therapy. Washington, DC: APA Press.

Hudson, P., \& O'Hanlon, W. (1991). Rewriting love stories: Brief marital therapy. New York: W. W. Norton and Company.

Miller, G., \& de Shazer, S. (2000). Emotions in solution-focused therapy: A reexamination. Family Process, 39(1), 5-23.

O'Hanlon, W., \& Beadle, S. (1997). A guide to possibility land. New York: W. W. Norton and Company.

O'Hanlon, W., \& Weiner-Davis, M. (1989). In search of solutions: A new direction in psychotherapy. New York: W. W. Norton and Company.

Sharry, J., Darmony, M., \& Madden, B. (2002). A solution-focused approach to working with clients who are suicidal. British Journal of Guidance and Counselling, 30(4), 383399.

Snyder, C. R., Ilardi, S. S., Cheavens, J., Michael, S. T., Yamhure, L., \& Sympson, S. (2000). The role of hope in cognitive-behavior therapies. Cognitive Therapy and Research, 24(6), 747-762.

Walter, J. L., \& Peller, J. E. (1992). Becoming solution-focused in brief therapy. New York: Brunner/Mazel Publishers.

Weiner-Davis, M. (1992). Divorce-busting: A step-by-step approach to making your marriage loving again. New York: Simon and Schuster Inc.

Young, M. E., \& Long, L. L. (1998). Counseling and therapy for couples. Pacific Grove: Brooks/Cole Publishing. 